\title{
EFFECTS OF ETHANOLIC EXTRACT OF RHINACANTHUS NASUTUS (L) KURZ AS AN ANTIMICROBIAL AGAINST ESCHERICHIA COLI BACTERIA USING IN VITRO METHOD
}

\author{
SUNARTI M. BIOMED ${ }^{1 *}$, DEBORA PANINSARI ${ }^{2}$ \\ ${ }^{1}$ Department of Biomedical, Faculty of Nursing and Midwifery, University of Prima Indonesia, Kota Medan, Sumatera Utara 20111, \\ Indonesia. ${ }^{2}$ Department of Maternity, Faculty of Nursing and Midwifery, University of Prima Indonesia, Kota Medan, Sumatera Utara \\ 20111, Indonesia. *Email: sunartibiomed@gmail.com \\ Received: 28 August 2019, Revised and Accepted: 14 October 2019
}

ABSTRACT

Objective: The objective of this study was to discover of the ethanolic extract of Rhinacanthus nasutus (L) Kurz in inhibiting Escherichia coli bacteria using an in vitro method.

Methods: This is an experimental study using a laboratory test with Kirby-Bauer or paper disc method by observing and measuring the inhibition zone of the ethanolic extract of R. nasutus against E. coli bacteria with extract concentrations of $15 \%, 30 \%$, and $60 \%$ consisting of control groups and treatment group. The positive control group used chloramphenicol antibiotics and negative control groups used Aquadest. $E$. coli was incubated at $37^{\circ} \mathrm{C}$ for $24 \mathrm{~h}$. Then, the plates were incubated for $24 \mathrm{~h}$ at $37^{\circ} \mathrm{C}$ and the diameter of the inhibition zone was observed until the $3^{\text {rd }}$ day with three repetitions.

Results: The results of the study showed that the mean inhibition zone of $E$. coli bacteria was $10.93 \mathrm{~mm}, 12.09 \mathrm{~mm}$, and $18.90 \mathrm{~mm}$. The results of the Shapiro-Wilk test were $\mathrm{p}=0.199$. The results of the one-way analysis of variance test were $\mathrm{p}<0.05$ and that of the post hoc test indicated a significant value of $\mathrm{p}<0.05$. Based on the results of the research, there were significant differences in the inhibition zone between the control group and the treatment group at a concentration of $15 \%, 30 \%$, and $60 \%$.

Conclusion: R. nasutus extract was effective to inhibit the growth of E. coli bacteria at concentrations of $15 \%, 30 \%$, and $60 \%$, so R. nasutus is effective as an antimicrobial.

Keywords: Rhinacanthus nasutus, Escherichia coli, Inhibition zone.

(c) 2019 The Authors. Published by Innovare Academic Sciences Pvt Ltd. This is an open access article under the CC BY license (http://creativecommons. org/licenses/by/4. 0/) DOI: http://dx.doi.org/10.22159/ajpcr.2019.v12i12.35523

\section{INTRODUCTION}

The various antibiotic resistance to microorganisms increases, which is caused by the use of uncontrolled free antibiotics for the treatment and disease prevention. It was an important to find alternative natural medicine as a safe antimicrobial agent. Therefore, there is a high interest in the study for the identification and development of natural antimicrobial compounds that are effective non-toxic and side effects [1].

Rhinacanthus nasutus is a natural antimicrobial spread out in several countries such as India, Southeast Asian countries, and China as traditional medicine [2]. Extracts of $R$. nasutus which have been identified to have very important secondary metabolites such as flavonoids, anthraquinones, triterpenes, and steroids, but there are the most active compounds, naphthoquinones. In naphthoquinone, the main compound is Rhinacantin C which is an active substance as an antimicrobial [3]. The use of $R$. nasutus leaves is more effective than its flowers, stems, and roots because the leaves of $R$. nasutus contain more secondary metabolites such as flavonoids, benzenoid, coumarin, anthraquinones, quinones, glycosides, triterpenes, sterols, and lupeol which are used as natural medicines. This plant is very effective as an antimicrobial [4].

Escherichia coli bacteria are bacteria found in human intestines; some strains of these bacteria may cause infectious diseases such as diarrhea, meningitis, septicemia, and urinary tract infection [5]. Diarrhea is a public health problem and a major cause of morbidity and mortality in infants and children [6]. Infectious diseases caused by E. coli increases because of resistance to antibiotic drugs [7]. It is found $6.9 \%$ of the 14 types of antibiotic drugs could inhibit bacterial growth [8]. Increased resistance of microorganisms to drugs was a global threat in therapy.
This can be caused by the use of synthetic drugs that ware irregular and incompatible with the pathogens of bacteria, viruses, and fungi and the presence of several chemicals inhibiting the action of antimicrobial drugs leading to changes in the target and ability of drugs to penetrate across bacterial cell wall [9].

Extract of $R$. nasutus had maximum bio-efficacy compared to other solvents because it had more compounds such as saponins, steroids, tannins, phenolic, triterpenoids, more alkaloids, and flavonoids that were produced using in vitro method and were able to inhibit pathogenic bacteria [10]. R. nasutus was able to reduce the activity of viruses causing herpes, namely, herpesvirus (HVS)-1 and HVS-2 [11]. R. nasutus root extract had quinonoid chemical content as an antimicrobial in Grampositive bacteria [12]. The importance of other alternatives to eradicate microbes resulted from increasing drug resistance; the researcher is interested to conduct this study. This study has a novelty to find out the antimicrobial activity of the ethanol extract of $R$. nasutus against Gramnegative bacteria (E. coli) in vitro at concentrations of 15,30 , and $60 \%$.

\section{METHODS}

\section{Research design}

This study was a true experiment using Kirby-Bauer or paper disc laboratory test method with observations and assessments of inhibition zones of the ethanolic extract of $R$. nasutus consisting of the control group and treatment group. The treatment group consisted of extract provision at concentrations of $15 \%, 30 \%$, and $60 \%$, positive control groups provided chloramphenicol, and negative control group provided Aquadest. The study was conducted in the Laboratory of Pharmacy and the Laboratory of Molecular Biology, Medical Faculty in University of Prima Indonesia. 
Plant material

The $R$. nasutus material comes from Pasar Gunung Village, North Sumatra Indonesia, then it was identified in the laboratory of the Herbarium Medanese Faculty of Biology in Universitas Sumatera Utara with letter number 1964/MEDA/2019.

\section{Preparation of $R$. nasutus extract}

$R$. nasutus leaves $2000 \mathrm{~g}$ were washed and then dried. After that, it is dried in a drying oven at $60^{\circ} \mathrm{C}$. After drying, it becomes simplicia weighing $520 \mathrm{~g}$ then crushed in an electric blender. The simplicia homogenate powder was macerated in $96 \%$ ethanol with a comparison of 1:10 in maceration jars for $72 \mathrm{~h}(3 \times 24 \mathrm{~h})$ occasionally stirred. Then, the filtrate is filtered with Whatman filter paper $(0.45 \mu)$. Then, the extract is evaporated using a rotary evaporator at a temperature range of $40-60^{\circ} \mathrm{C}$ until it thickens. The result is then applied with a porcelain dish until a thick extract is obtained [13].

\section{Phytochemical screening}

The results of the extract were evaluated to investigate the phytochemical tests such as alkaloids, steroids, and triterpenes, saponins, flavonoids, tannins, and glycosides [14].

\section{Preparation of $E$. coli bacteria and experimental procedures}

The E. coli bacteria were obtained from the Laboratory of Microbiology at the University of Sumatera Utara. The materials used in this study were sterilized. Petri dishes, test tubes, Erlenmeyer flask, measuring cups, use needles, and stirring rods were washed, dried, and wrapped in clean clothes. Then, these tools were sterilized in a sterilizer (Hot air oven) at $160^{\circ} \mathrm{C}$. Materials to be used such as Mueller-Hilton Agar, nutrient agar, and Aquadest were sterilized by autoclaving at $121^{\circ} \mathrm{C}$ for $15 \mathrm{~min}$. The other tools were sterilized in alcohol with a concentration of $70 \%$ and fire spirits [15]. Bacterial suspensions were made by taking E. coli bacteria colonies using a test tube containing $0.9 \%$ of $\mathrm{NaCl}$ (physiological) and osemata. They were then mixed in a vortex to make them homogeneous. Inoculum is made in accordance with McFarland standard, i.e. 0.5 to obtain $1.5 \times 108 \mathrm{cell} / \mathrm{ml}$ of bacteria. Next, the suspension was put into brain heart infusion plates in a test tube and incubated at $37^{\circ} \mathrm{C}$ for $6-10 \mathrm{~h}$. Then, the suspension was planted in natrium plates by rubbing the E. coli culture using a sterile cotton stick. The disc paper (diameter of $6 \mathrm{~mm}$ ) of the treatment group was infused with extracts of $R$. nasutus at a concentration of $15 \%, 30 \%$, and $60 \%$. The disc papers of positive control and negative control groups were infused with chloramphenicol and Aquadest, respectively. They were placed on agar plates which had been inoculated with $E$. coli bacteria at $4^{\circ} \mathrm{C}$ for $2 \mathrm{~h}$, and the bacteria were then incubated at $37^{\circ} \mathrm{C}$ for the next $24 \mathrm{~h}$ to measure the diameter of its inhibition zone using the calipers [16]. All tests were carried out in three repetitions and tested by Kirby-Bauer agar diffusion method using a paper disc with a diameter of $6 \mathrm{~mm}$ [17].

\section{Statistical analysis}

The data were presented in the mean and deviation standard. The research used primary data that were tested with SPSS 25.0 for Windows. The data were tested for normality with Shapiro-Wilk. If they were normally distributed, they would then be tested using one-way ANOVA (analysis of variance) and a post hoc test at $\alpha<0.05$.

\section{Ethical clearance}

This study was conducted pursuant to the ethical clearance governed by the Animal Ethics Committee of Faculty of Mathematics and Natural Sciences, University of Sumatera Utara, Medan, under a letter numbered: 0292/KEPK-FMIPA/2019.

\section{RESULTS AND DISCUSSION}

\section{Phytochemical screening}

The phytochemical screening of the ethanol extract of $R$. nasutus discovered alkaloid, saponin, tannin, flavonoid, steroid, and triterpene; while glycoside was not found. These results are illustrated, as shown in Table 1.
Inhibition zone of $E$. coli bacteria

The inhibition zones of $E$. coli that was formed around the disc are presented (Fig. 1), and it is tabulated in Table 2. Mean zones of inhibition of the ethanolic extract $R$. nasutus against $E$. coli were calculated and tabulated in Table 3

The results of the normality test with the Shapiro-Wilk test showed $\mathrm{p}=0.199$. The results of one-way ANOVA test showed significant differences in the inhibition zones of $E$. coli with $\mathrm{p}=0.000$. To discover which groups experienced differences from the results of this assessment, the post hoc test was conducted. The test results were indicated by differences in the notation of each group with a significance value of $\alpha<0.05$. The results of the post hoc test demonstrated that there were significant differences between the control group and the treatment group using the extract at a concentration of $15 \%, 30 \%$, and $60 \%$ with the values of each $p=0.000$, as shown in Table 4 . This indicated that there was a significant increase in the inhibition zone of the ethanolic extract of $R$. nasutus against Gram-negative bacteria (E. coli).

E. coli is a bacterium that causes diarrhea. Diarrhea is a condition in which there is an increased frequency of defecation and decreased consistency. Diarrhea can also be chronic and even cause death due to dehydration when not treated properly, especially if there is a loss of

Table 1: Phytochemical screening of the ethanol extract of Rhinacanthus nasutus

\begin{tabular}{lc}
\hline Phytochemical test & Extract test \\
\hline Alkaloids & + \\
Saponin & + \\
Tannins & + \\
Flavonoids & + \\
Steroids & + \\
Triterpenes & + \\
Glycosides & - \\
\hline (+): Present, (-): Absent
\end{tabular}

Table 2: Inhibition zone of Escherichia coli bacteria

\begin{tabular}{lccc}
\hline Treatment group & Group I & Group II & Group III \\
\hline K0 & 0 & 0 & 0 \\
K1 & $20.30 \mathrm{~mm}$ & $23.00 \mathrm{~mm}$ & $25.90 \mathrm{~mm}$ \\
P1 & $10.60 \mathrm{~mm}$ & $11.85 \mathrm{~mm}$ & $10.35 \mathrm{~mm}$ \\
P2 & $12.70 \mathrm{~mm}$ & $13.05 \mathrm{~mm}$ & $10.55 \mathrm{~mm}$ \\
P3 & $18.65 \mathrm{~mm}$ & $20.25 \mathrm{~mm}$ & $17.80 \mathrm{~mm}$ \\
\hline
\end{tabular}

Table 3: Mean of inhibition zone values in Escherichia coli bacteria

\begin{tabular}{ll}
\hline $\begin{array}{l}\text { Treatment group } \\
\text { Escherichia coli }\end{array}$ & $\begin{array}{l}\text { Inhibition zone } \\
\text { (Mean } \pm \text { SD) }\end{array}$ \\
\hline K0 & $0.00 \pm 0.00$ \\
K1 & $23.07 \pm 2.80$ \\
P1 & $10.93 \pm 0.80$ \\
P2 & $12.09 \pm 1.35$ \\
P3 & $18.90 \pm 1.24$ \\
\hline
\end{tabular}

SD: Standard deviation

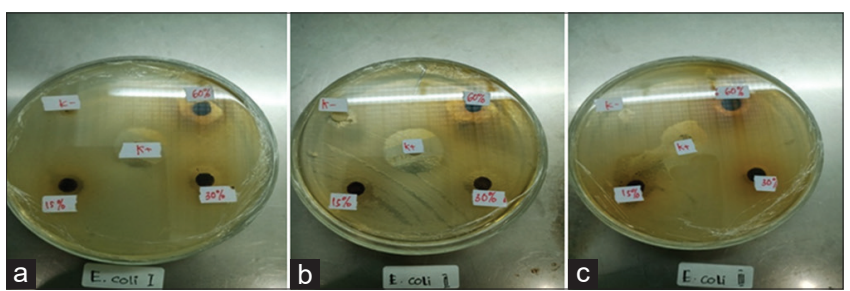

Fig. 1: Description of inhibition zone of Escherichia coli bacteria 
Table 4: Antimicrobial activity of ethanolic extract of Rhinacanthus nasutus

\begin{tabular}{lc}
\hline Treatment group & Inhibition zone (p-value) \\
\hline K0-K1 & $0.000^{*}$ \\
K0-P1 & $0.000^{*}$ \\
K0-P2 & $0.000^{*}$ \\
K0-P3 & $0.000^{*}$ \\
\hline
\end{tabular}

post hoc test $* \mathrm{p}<0.05$

body fluids and salt, namely, sodium and potassium, especially in the elderly and infants [18].

The resistance of various antimicrobial drugs occurs due to the free and widespread use of antimicrobials over many years so that it can cause changes in the profile of pathogenic microbial isolates cause of diarrhea. Besides, those synthetic drugs can cause various side effects. Hence, it is necessary to develop antimicrobials from natural compounds for the production of new drugs with a minimal side effect [19]. The development of antibacterial drugs based on natural products has been developed at this time; this can be caused by the use of synthetic antibacterial drugs in the long term which can cause many side effects also become resistant to antibiotics [20]

The results of this study indicate that the ethanolic extract of $R$. nasutus contains secondary metabolites such as alkaloids, flavonoids, saponins, tannins, steroids, and triterpenes. This study is consistent with previous studies, which suggested that the main naphthoquinone, i.e. Rhinacanthins- $\mathrm{C},-\mathrm{N}$, and $-\mathrm{Q}$ of $R$. nasutus had antibacterial potential by showing strong antibacterial activity against $\beta$-hemolytic streptococci, enterococci, and staphylococci, with its potential comparable to antibiotic gentamicin drugs [21]. Some of the important biological activities in $R$. nasutus are anticancer, antibacterial, and anti-inflammatory, which are associated with the presence of various functional compounds such as carotenoids, flavonoids, phenolic acids, chlorophyll, and naphthoquinones [22]

The results of the study found that $R$. nasutus can be used as a natural antibacterial, supported by another study that found that $R$. nasutus was a strong antibacterial against Staphylococcus epidermidis with a dose of $1000 \mu \mathrm{g} / \mathrm{ml}$ and $500 \mu \mathrm{g} / \mathrm{ml}$ [23]. Based on the results of the study, on inhibition zones, the control group (K0) using Aquadest did not show any inhibition zones in $E$. coli because the Aquadest did not have any antibacterial effect. This group was then compared to $R$. nasutus extract at concentrations of $15 \%, 30 \%$, and $60 \%$ which showed significant results, i.e., it increased the inhibition zone in $E$. coli bacteria. The previous study also found that the active substance of Rhinacantin A of $R$. nasutus plant could increase the inhibition zone of Staphylococcus aureus with inhibition zones of $16 \mathrm{~mm}$ and $20 \mathrm{~mm}$ at $25 \mu \mathrm{g} / \mathrm{disc}$ and Mycobacterium smegmatis compounds (20 mm at $25 \mu \mathrm{g} / \mathrm{disc}$ ) [24].

\section{CONCLUSION}

The results of the study showed a significant increase in the inhibition zone of ethanol extract Rhinacanthus nasutus against Escherichia coli bacteria at concentrations of 15,30 and $60 \%$. So that the ethanol extract of Rhinacanthus nasutus is effective as an antimicrobial.

\section{ACKNOWLEDGMENT}

The authors are especially grateful to the Directorate General of Higher Education (Ditjen Dikti) who has provided the fund to support this research. Gratitudes are also expressed to the University of Prima Indonesia, the laboratory assistants who have helped to conduct this research, and close friends who have supported this study.

\section{AUTHORS' CONTRIBUTIONS}

Debora Paninsari contributed to the collection of the plant sample and sample bacteria; Sunarti has carried out extraction and phytochemical screening, Preparation of E. coli bacteria and measure the diameter of inhibition zone, contributed to the study guide and coordinated the manuscript writing, editing, and finalization.

\section{CONFLICTS OF INTEREST}

Authors declare that they have no conflicts of interest, the research subject, and others.

\section{REFERENCES}

1. Islam A, Islam $\mathrm{S}$, Hossain $\mathrm{A}, \mathrm{Ahmed} \mathrm{S}$. In vitro antibacterial activity of medicinal plants turmeric, chinnamon, and clove against GM (+VE) and GM (-VE) bacteria. Int J Curr Pharm Res 2019;11:585-8.

2. Makvana, S, Krilov L. Escherichia coli infections. Pediatr Rev 2015;36:4 167-71.

3. Gomes TA, Elias WP, Scaletsky IC, Guth BE, Rodrigues JF, Piazza RM, et al. Diarrheagenic Escherichia coli. Braz J Microbiol 2016;47 Suppl 1:3-0.

4. Lee DS, Lee SJ, Choe HS. Community-acquired urinary tract infection by Escherichia coli in the era of antibiotic resistance. Biomed Res Int 2018;2018:7656752

5. Cho S, Hiott LM, Barrett JB, McMillan EA, House SL, Humayoun SB, et al. Prevalence and characterization of Escherichia coli isolated from the upper oconee watershed in Northeast Georgia. PLoS One 2018;13:e0197005.

6. Yadav AK, Ambasta SK, Prasad SK, Trivedi MP. In vitro evaluation of antimicrobial property of Catharanthus roseus (Linn.) G. Don. Var. "Rosea" and "Alba". Int J Pharm Pharm Sci 2018;10:555-8.

7. Bhusal N, Panichayupakaranant $\mathrm{P}$, Reanmongkol W. In vivo analgesic and anti-inflammatory activities of a standardized Rhinacanthus nasutus leaf extract in comparison with its major active constituent rhinacanthin-C. Songklanakarin J Sci Technol 2014;36:3325-31.

8. Fadli A, Jekti D, Bahri S. Toxicity test of methanol extractof Rhinacanthus nasutus L.Kurz. Leaf to Spodoptera litura F. IOSR J Environ Sci Toxicol Food Technol 2017;11:1260-3.

9. Antonysamy J. In vitro phytochemical and antibacterial studies on Rhinacanthus nasutus (L.) Kurz a medicinally important plant. J Microbiol Exp 2017;4:21-4.

10. Rao PV, Goudu AS, Sasikala S, Naidu MD. Efficacy of antimicrobial activity of Rhinacanthus nasutus (LINN) leaves in different extractions. Int J Pharma Bio Sci 2010;1:21-4.

11. Chaliewchalad P, Thongwai N, Tragoolpua Y. Inhibitory effect of Rhinacanthus nasutus (Linn.) Kurz. and Stemona tuberosa (Lour.) extracts on herpes simplex virus infection. J Med Plants Res 2013;7:276-84.

12. Chansukh K, Charoensup R, Palanuvej CC, Ruangrungsi NN. Antimicrobial activities of selected Thai medicinal plants bearing quinonoids. Res J Pharm Biol Chem Sci 2014;5:2425-32.

13. Sunarti S, Fachrial E, Harahap U, Delyuzar D, Widyawati T, Dona L. Hepatoprotective effect of red ginger rhizome extract in deep frying oil-fed male Wistar rats. Univ Med 2017;36:3228-35.

14. Jain HK, Jaiswal SR. Effect ofco-administration of Emblica officinalis and Aegle marmelos extracts for antioxidant and antidiabetic activity. Int J Pharm Pharm Sci 2019;11:781-9.

15. Mubarak Z, Chrismirina S, Daulay HH. Antibacterial activity of natural propolis extract from beehives against the growth of Enterococcus faecalis. J Syiah Kuala Dent Soc 2016;1:2175-86.

16. Smahane B, Mounyr B, Faisl B, Stephane M, Sghir TM, Dalila B. Antimicrobial activities of essential oil of five plant species from Morocco against some microbial strains. Int J Pharmacogn Phytochem Res 2016;8:111901-6.

17. Silalahi J, Situmorang P, Patilaya P, Silalahi YC. Antibacterial activity of chitosan and hydrolyzed coconut oil and their combination against Bacillus cereus and Escherichia coli. Asian J Pharm Clin Res 2016;9:569-73.

18. Diansari E, Suwarso E, Dalimunthe A. Anti diarrhea effect of ethanol extract kecapi bark (Sandoricum koetjape Merr) on male guinea pig induced with castor oil and bacteria Escherichia coli. Asian J Pharm Clin Res 2018;11:173-6.

19. Jindal M, Chauhan S. In vitro comparison of the antibacterial activity of ethanolic extract of Azadirachta indica leaves with gentamycin, ampicillin, nitrofurantoin, and cotrimoxazole on bacterial pathogens isolated from urinary tract infection patients. Asian $\mathrm{J}$ Pharm Clin Res 2017; 10:872-4.

20. Kumala S, Rahmat D, Farida Y, Benny. Antibacterial activity of ethanolic extract of javanese turmeric rhizome entrappted in nanoparticles: 
A novel rule of chitosan. Int J Appl Pharm 2018;10:6298-302.

21. Siripong P, Wongseri V, Piyaviriyakul S, Yahaufai J, Chanpai R, Kanokmedakul K. Antibacterial potential of Rhinacanthus nasutus against clinically isolated bacteria from Thai cancer patients. Mahidol univ. J. Pharm Sci 2006;33:415-22.

22. Thongrod S, Yincharoen K. Antibacterial of a traditional Thai herbal recipe (THR 01) against Staphylococcus epidermidis antibacterial activity was evaluated by the broth macrodilution. Int J Agric Technol
2017;13:131-6.

23. Ho NH, Inbaraj BS, Chen BH. Utilization of microemulsions from Rhinacanthus nasutus (L.) kurz to improve carotenoid bioavailability. Sci Rep 2016;6:25426.

24. Maarisit W, Yamazaki H, Abdjul DB, Takahashi O, Kirikoshi R, Namikoshi $\mathrm{M}$, et al. A new pyranonaphtoquinone derivative, 4-oxorhinacanthin a, from roots of Indonesian Rhinacanthus nasutus. Chem Pharm Bull (Tokyo) 2017;65:586-8. 